\title{
Documentation of tree species within Mizoram Science Centre, Berawtlang, Aizawl, India, with notes on their ethnomedicinal values
}

\author{
Lalrinkimi $^{*}{ }^{*}$, R.K. Lallianthanga ${ }^{2}$ \\ ${ }^{1}$ Mizoram Science Centre, Berawtlang, 796017, India \\ ${ }^{2}$ Directorate of Science and Technology, Mizoram New Capital Complex 796001, India
}

\begin{abstract}
This study provides a first report of the various tree species prevailing in the tropical semi-evergreen forest within Mizoram Science Centre, Berawtlang, Aizawl in relation to their diversity; and also mentions traditional ethnomedicinal and economic uses of the species. A total number of 776 individual trees were assessed within the study site belonging to 74 different species representing 61 genera and 34 families. Among these, 55 tree species have been reported by previous workers to possess indigenous medicinal values. The most abundant tree species at the study site was found to be Callicarpa arborea (hnahkiah) of Verbenaceae comprising $14.30 \%$ of the total trees assessed, followed by Anogeissus acuminata (zairum) of Combretaceae with 12.62\%, and Schima wallichii (khiang) of Theaceae with $10.56 \%$. A concise list of the species recorded along with their ethnomedicinal and economic uses have been presented here. The prospect of in situ conservation of tree species is briefly highlighted.
\end{abstract}

Keywords: Tree species, ethnomedicinal trees, in situ conservation, Mizoram Science Centre, Documentation.

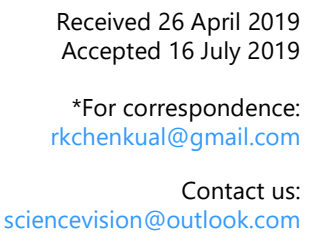

\section{Introduction}

Among the 36 biodiversity hotspots of the world, Mizoram, one of the northeastern states of India forms a part of the Indo-Myanmar hotspot region. These hotspots are characterized by highest levels of endemism with corresponding high loss of natural habitats. ${ }^{1}$ It has been reported that Northeast India has nearly $64 \%$ of its total geographical area under forest cover, harboring approximately 7500 angiospermic species. ${ }^{2}$ Mizoram shares international boundaries with Bangladesh in the West, and with Myanmar in the East and South. It also shares interstate borders with Assam, Tripura and Manipur. The forest cover in Mizoram is 18,186 sq km accounting for $86.27 \%$ of its total geographical area. ${ }^{3}$ The state has a rich diversity of flora and fauna with a wealth of medicinal plants as reported by various workers. $^{2,4-6}$ The natural forests of the tropical and sub-tropical forests of Mizoram are highly overexploited for medicinal plants, collection of fuel wood and timber, and for shifting cultivation. ${ }^{7}$

The study area, Mizoram Science Centre (MSC) campus, which is under the jurisdiction of the Government of Mizoram falls under tropical semievergreen forest based on classification by Champion and Seth. ${ }^{8}$ The tropical forests have been described to offer essential ecological services including habitat preservation and species conservation for both flora and fauna, and prevention of soil erosion. ${ }^{9}$ It was assumed that the study site also harbors a diverse number of tree 
species in its tropical semi-evergreen forest which may be associated with a wealth of fauna. To confirm this assumption, a detailed documentation of the tree species composition was accomplished as a first step towards understanding the floristic diversity within the area.

This paper presents the prevailing tree species of the area in relation to their diversity and indicates ethnomedicinal and traditional economic uses of the tree species. The area was found to harbor a number of traditionally important medicinal plants, and the mode of utilization of these ethnomedicinal plants as reported by previous studies have been emphasized in this paper. The present study is significant as it is highly anticipated to aid in conservation and management of the area's flora in the future, when plans for augmenting and developing the infrastructure of MSC are designed and formulated. Information generated from this tree species inventory will contribute to enhance our knowledge regarding tropical forest biodiversity of the state.

\section{Materials and Methods}

The study site, Mizoram Science Centre, has an area of $23.057 \mathrm{sq} \mathrm{km}$ and lies in the eastern part of Aizawl, the capital of Mizoram. It is located between $92^{\circ} 45^{\prime} 53.85^{\prime \prime} \mathrm{E}-92^{\circ} 45^{\prime} 55.74^{\prime \prime} \mathrm{E}$ longitudes and $23^{\circ}$

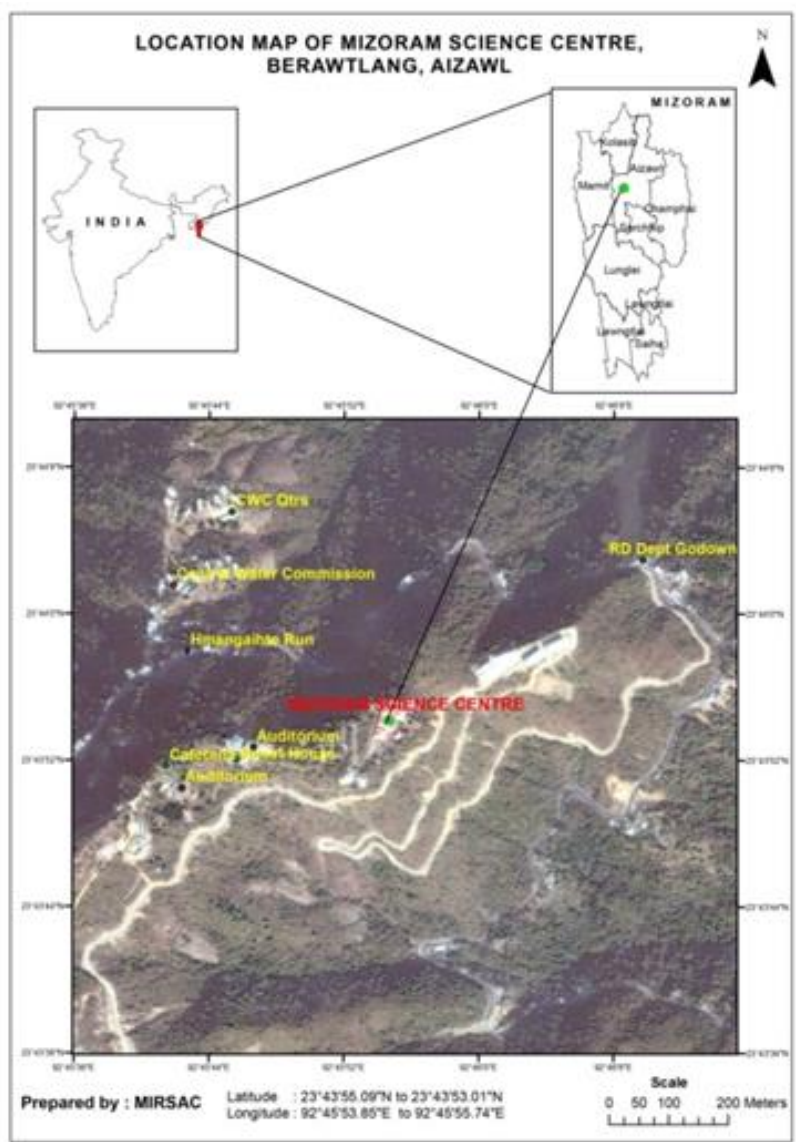

Figure 1 | Location map of Mizoram Science Centre, Berawtlang. $43^{\prime} 55.09^{\prime \prime} \mathrm{N}-23^{\circ} 43^{\prime} 53.01^{\prime \prime} \mathrm{N}$ latitudes (Figure 1). Documentation of the tree species present within the study area was conducted out during March to July 2018. During this period, frequent field surveys of the site (Figure 2) were carried out for collection, identification and documentation. Trees having diameter at breast height (DBH) larger than $5 \mathrm{~cm}$ were selected for assessment. Photographs of the plants were taken in situ for multiple tree species, and for others, plant parts including branches with leaves, flowers and fruits were collected and photographed for identification purposes. Photographs of the species were taken using Canon 600D camera equipped with 18-135 STM lens. Various local key informants and taxonomists from Pachhunga University College, Aizawl, were employed and consulted in assigning the vernacular names of plant specimens. Descriptions of species were prepared using standard literatures including the books of Flora of Mizoram Vol $I{ }^{10}$ and The Book of Mizoram Plants. ${ }^{11}$ Threat assessment of the species was made based on The IUCN Red List of Threatened Species. ${ }^{12}$

\section{Results}

\section{Species composition}

In this study, a total number of 776 individual

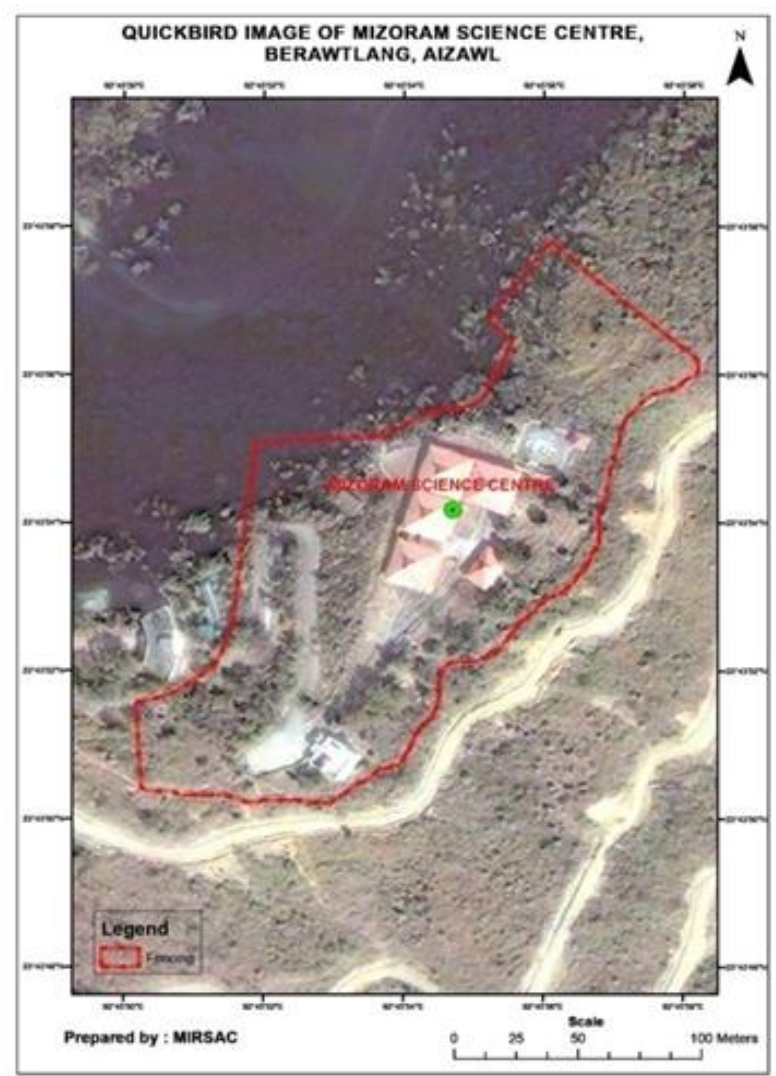

Figure 2 | Satellite image of Mizoram Science Centre, Berawtlang. 
trees were assessed within the study site which belongs to 74 different species representing 61 genera and 34 families. Among these, 55 species were previously reported by various workers to possess medicinal values. Table 1 provides a detailed account of the different tree species documented from the study area with their economic uses.

\section{Ethnomedicinal plants}

The ethnomedicinal tree species with their medicinal usage as reported by previous works are as follows:

Acer oblongum Wall. ex DC. Family: Aceraceae. Mizo Name: Thing-phing-phi-hlip. Mode of Use: Decoction of leaves and bark used against fever, stomach problem, food poisoning and retained placenta. $^{11}$

Alangium chinense (Lour.) Harms. Family: Alangiaceae. Mizo Name: Ar-sa-rim-nam. Mode of Utilization: Roots and stems are used as carminative and blood tonic, for treating wounds, rheumatism etc. ${ }^{11}$

Albizia chinensis (Osb) Merr. Family: Mimosaceae. Mizo Name: Vang. Mode of Utilization: A brew of the bark is used in cuts, scabies and various dermal problems. ${ }^{2,11}$

Albizia odoratissima (L.f.) Benth. Family: Mimosaceae. Mizo Name: Thing-ri. Mode of Utilization: Bark and leaves are used against certain ailments. ${ }^{11}$

Albizia procera (Roxb.) Benth. Family: Mimosaceae. Mizo Name: Kang-țek. Mode of Utilization: Decoction of bark taken against pinworms/threadworms etc. Poultices are prepared from leaves to treat ulcers. $2,4,11$

\begin{abstract}
Alstonia scholaris (L.) R. Br. Family: Apocynaceae. Mizo Name: Thuam-riat. Mode of Utilization: Decoction of the bark and leaves are taken to treat headache, influenza, bronchitis, and pneumonia. Bark decoction is used for treating hypertension, asthma, fever, typhoid, malaria, stomach ulcer, diarrhea and dysentery. Milky juice obtained from bark is applied to snake-bites, cuts, sores and other skin diseases. ${ }^{2,11}$
\end{abstract}

Anogeissus acuminata (Roxb. ex DC) Guill. Family: Combretaceae. Mizo Name: Zai-rum. Mode of Utilization: Decoction of bark taken as hemostatic agent, for stomach problems, diarrhoea, fever, beriberi, also applied on skin problems like measles, chicken-pox including sprains and burns. Leave infusion is used in hypertension. $2,4,5,11$
Aporosa octandra (Buch.-Ham. ex D. Don) Vickery. Family: Euphorbiaceae. Mizo Name: Chhâwn-tual. Mode of Utilization: Stem-bark decoction is taken against stomach ulcer, gout, rheumatism, diarrhea and dysentery. Young leaves decoction is also taken for stomach ailments. $^{2,5,6,11}$

Areca catechu Linn. Family: Arecaceae. Mizo Name: Kuhva-kung. Mode of Utilization: Seeds are taken against intestinal worms. A powdered mixture of the nuts with bulb of Aginata indica L., root of Cissisrependa Vahl. and leaves of Piper betle $\mathrm{L}$. are made into pills and taken during menstrual periods by Bru people. ${ }^{2,11}$

Artocarpus heterophyllus Lam. Family: Moraceae. Mizo Name: Lâm-khuang. Mode of Utilization: Root decoction used against asthma, diarrhoea, fever and sterility in women. Leaves are useful against fever, skin diseases, wounds, boils, etc. The milky juice is useful for herpes eruptions. 4,1

Artocarpus lakoocha Roxb. Family: Moraceae. Mizo Name: Thei-tât. Mode of Utilization: Seed used as laxative. Crushed bark juice is applied on pimples, face acne and crack skin. Bark powder is applied on sores to extract excretion. ${ }^{2,411}$

Bauhinia variegata L. Family: Caesalpiniaceae. Mizo Name: Vau-be. Mode of Utilization: Bark/ leaves decoction taken orally against diabetes, menstrual disorders, intestinal worms, diarrhoea, piles and dysentery. ${ }^{2,11}$

Bischofia javanica Blume. Family: Euphorbiaceae. Mizo Name: Khuang-thli. Mode of Utilization: Juice of tender leaves taken orally against tonsillitis, cholera and sores. Its stem and bark has medicinal uses. Roots are used for treating chronic rheumatic pain and malaria. ${ }^{2,5,11}$

Bombax insigne Wall. Family: Bombacaceae. Mizo Name: Pâng. Mode of Utilization: Bark decoction with that of Mangifera indica (equal parts) is used for tonsillitis and other throat infections. ${ }^{4,5,11}$

Callicarpa arborea Roxb. (Figure 3A). Family: Verbenaceae. Mizo Name: Hnah-kiah. Mode of Utilization: Bark and leaves decoctions are used against diabetes, and various forms of stomach ailments including internal bleeding. Decoction of mixture of leaves with leaves of Byttneria pilosa, stem-bark of Ficus semicordata and whole plant of Phyllanthus fraternusis used for jaundice and hepatitis. $2,4,11$

Castanopsis tribuloides (Sm.) A. DC. (Figure 3B). 


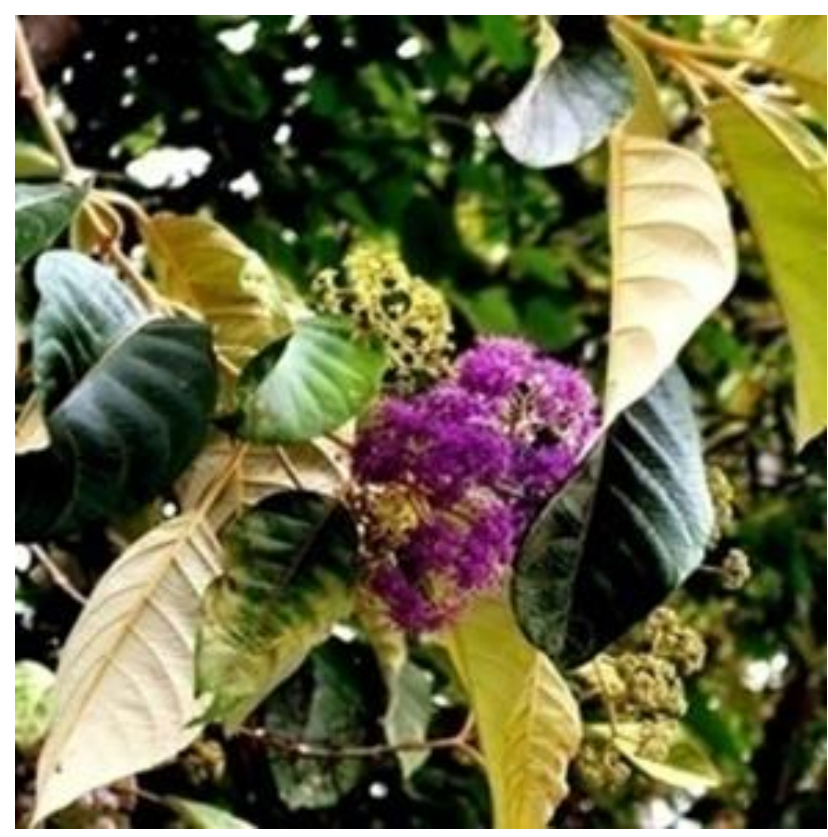

A. Callicarpa arborea (hnahkiah)

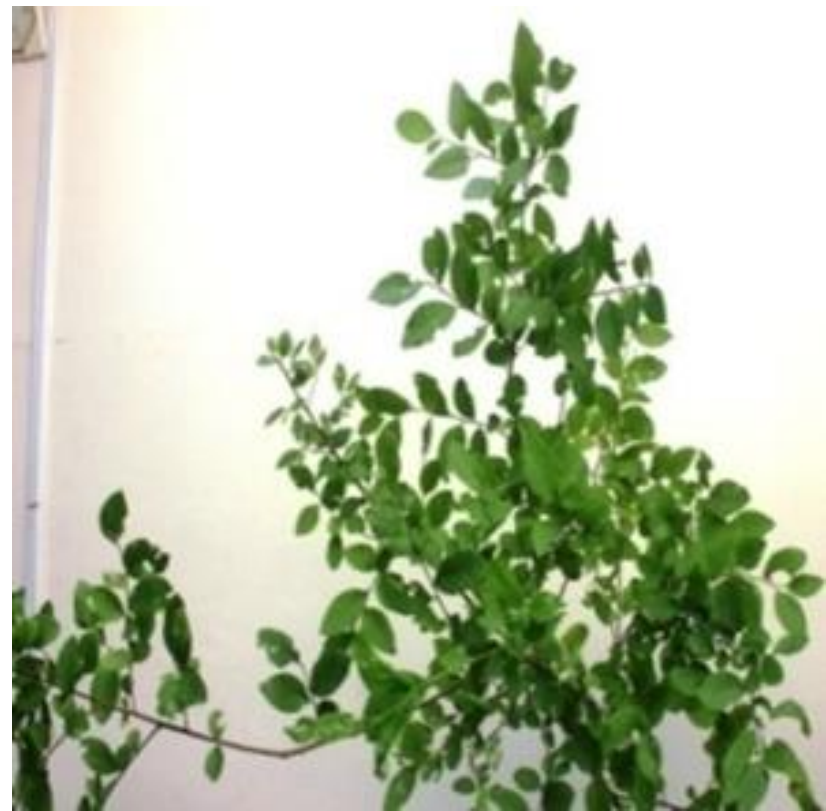

C. Flueggea virosa (saisiak)

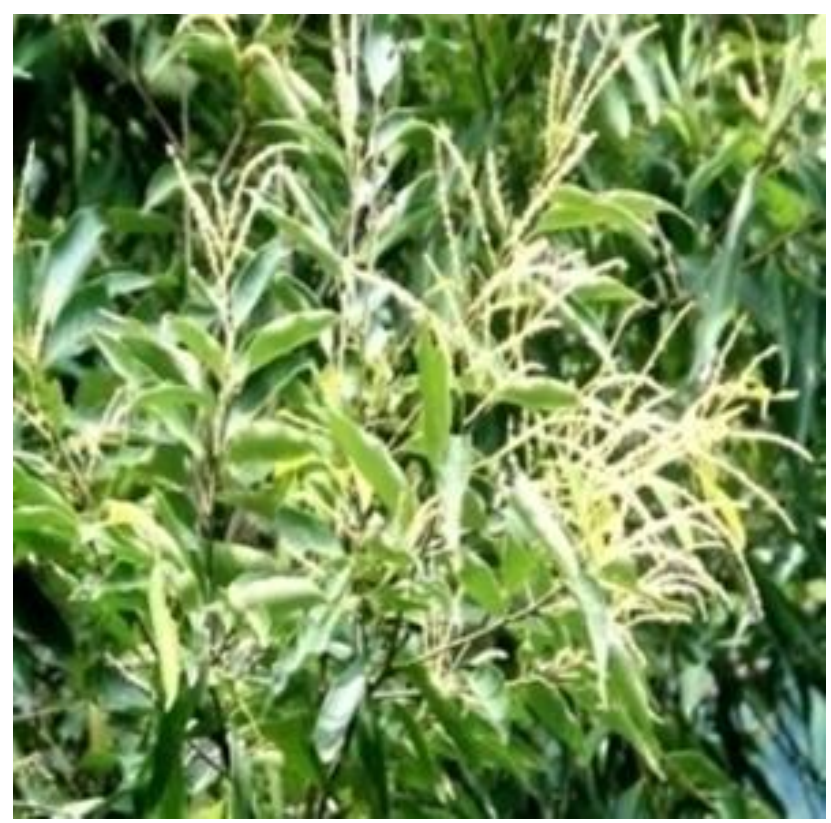

B. Castanopsis tribuloides (thingsia)

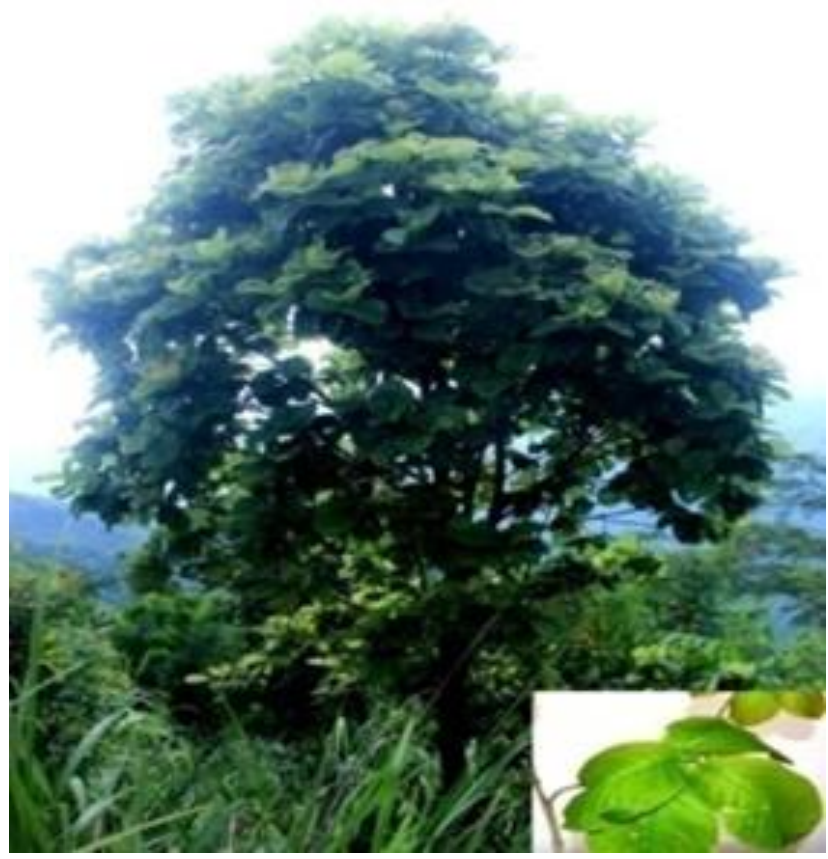

D. Haldina cordifolia (lungkhup) 


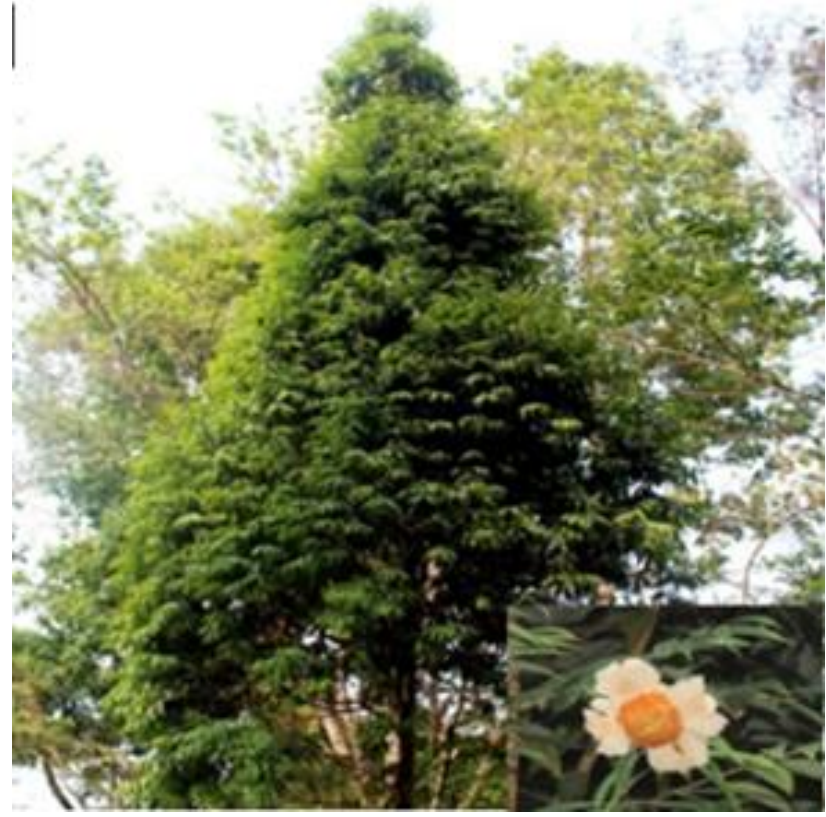

E. Mesua ferrea (herhse)

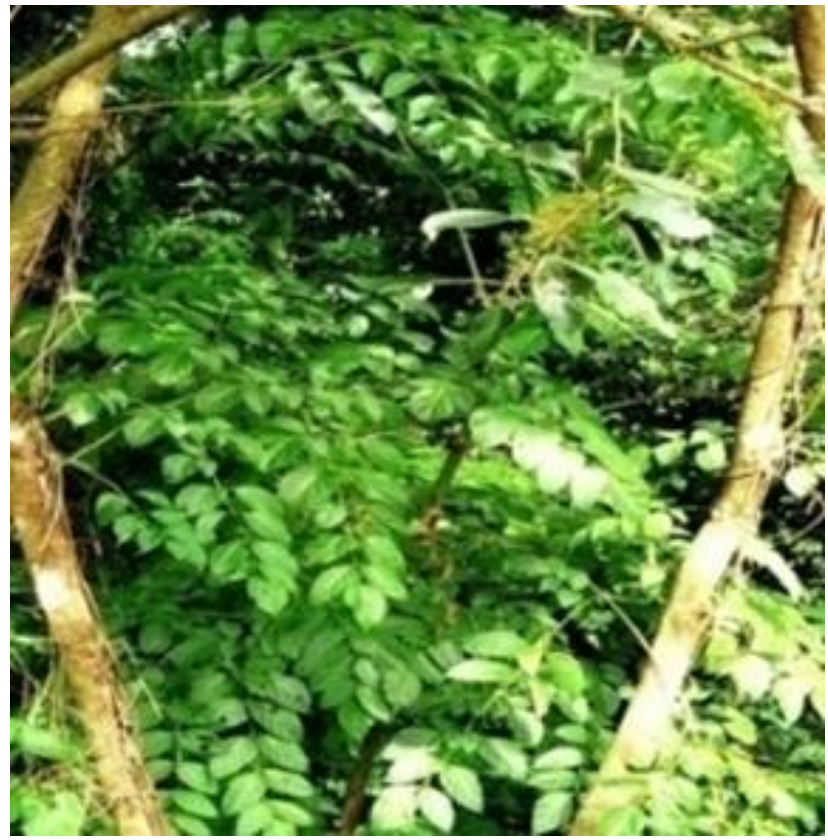

G. Oroxylum indicum (archangkâwm)

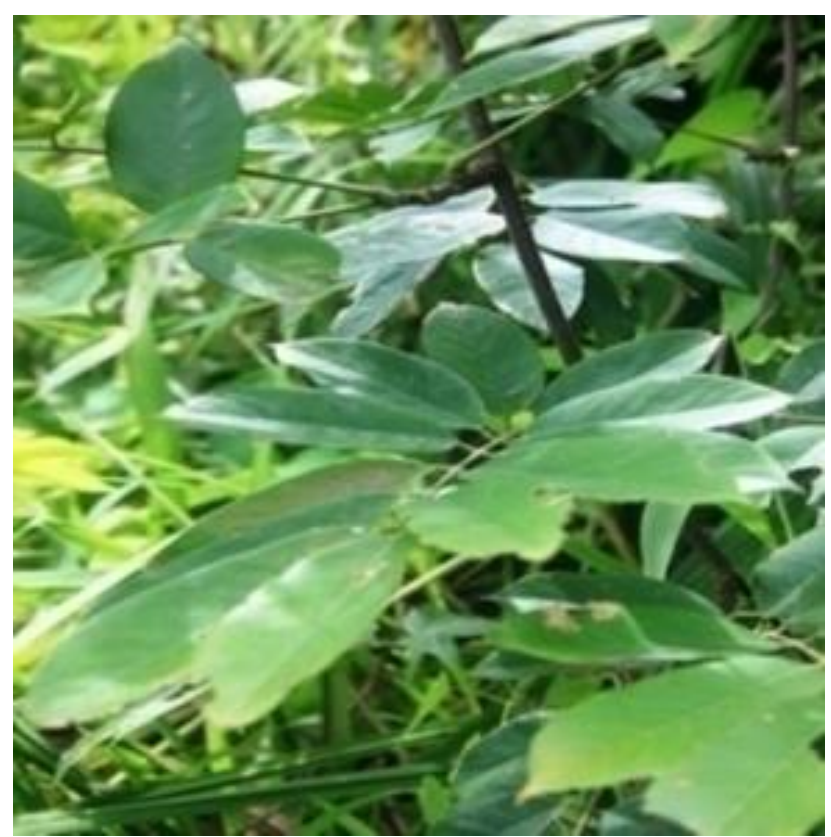

F. Milletia pachycarpa (rulei)

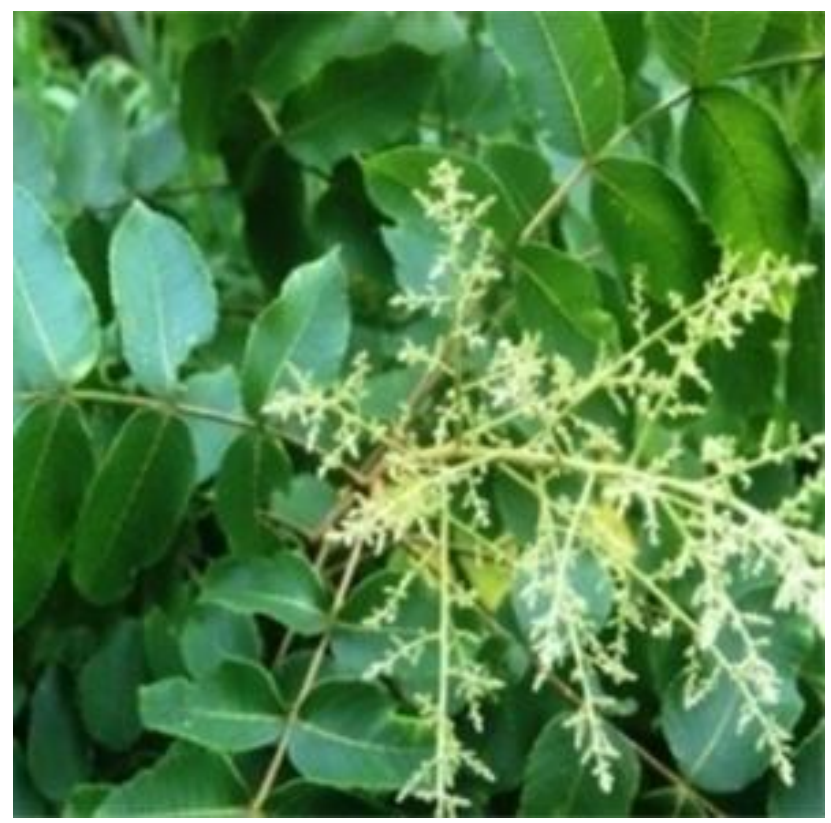

H. Rhus chinensis (khawmhma) 


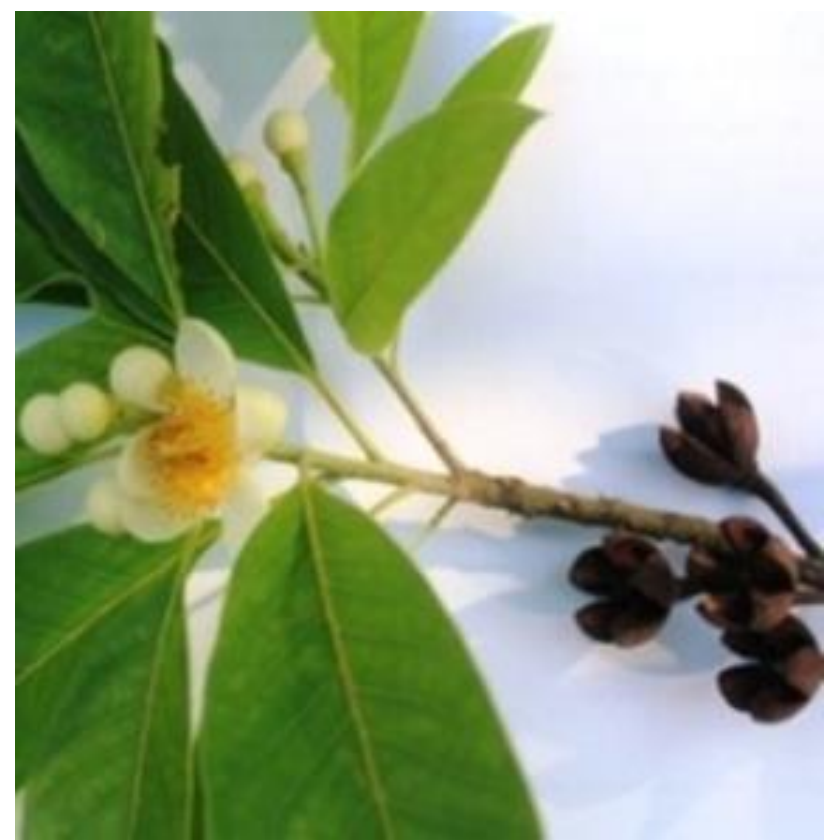

I. Schima wallichii (khiang)

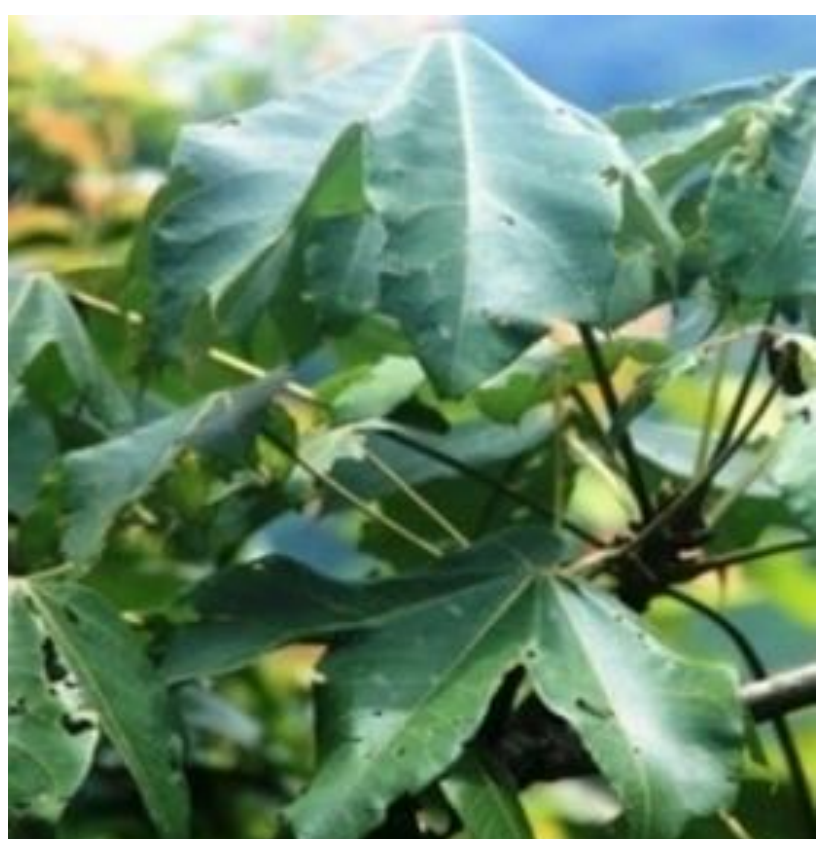

J. Sterculia villosa (khaupui)

Figure 3 | Interesting tree species (A-J) at Mizoram Science Centre Campus.

Family: Fagaceae. Mizo Name: Thing-sia. Mode of Utilization: Stem juice is applied in mouth infection in children. ${ }^{11}$

Cerasus cerasoides (Buch.-Ham. ex D. Don) S. Y. Sokolov. Family: Rosaceae. Mizo Name: Tlaizawng. Mode of Utilization: Bark decoction is used against fever. ${ }^{2,11}$

Cinnamomum tamala (Buch.-Ham.) T. Nees \& Eber. Family: Lauraceae. Mizo Name: Tespata/ Hnah-rimtui. Mode of Utilization: Grinded bark is mixed with water and used for diabetes. ${ }^{2,6,11}$

Cordia fragrantissima Kurz. Family: Boraginaceae. Mizo Name: Muk. Mode of Utilization: Decoction of the bark/leaves is prescribed for expelling small pieces of retained placenta. ${ }^{11}$

Derris robusta (Roxb. ex DC) Benth. Family: Fabaceae. Mizo Name: Thing-kha. Mode of Utilization: Bark decoction is taken against hypertension and diabetes. ${ }^{11}$

Engelhardia spicata Lesch ex Blume. Family: Juglandaceae. Mizo Name: Hnûm. Mode of Utilization: Root decoction is taken against diarrhea and dysentery. ${ }^{2,11}$

Erythrina stricta Roxb. Family: Fabaceae. Mizo Name: Far-țah. Mode of Utilization: Bark decoction is used against stomach ulcer and kidney disorder. Powdered bark is used in snakebite, fever, asthma, nausea, rheumatism, skin irritation, leprosy, epilepsy and as an astringent. ${ }^{2,11}$

Ficus hirta Vahl. Family: Moraceae. Mizo Name: Sazu- thei-pui. Parts Used: Roots are believed to have medicinal properties. ${ }^{11}$

Ficus hispida L. f. Family: Moraceae. Mizo Name: Paih-te-mai-an. Mode of Utilization: The bark, fruit and seeds are used in cases of jaundice, anaemia and fever. Leave decoction is used for inflamed kidneys and urinary disorder. Juice obtained from leaves heated on fire is used for eye ailments. ${ }^{11}$

Ficus prostrate (Wall. ex Miq.) Buch.-Ham. ex Miq. Family: Moraceae. Mizo Name: Thei-tit. Mode of Utilization: Juice from roots the white latex are used in snake bites. ${ }^{4,11}$

Ficus retusa L. Family: Moraceae. Mizo Name: Ri -hnim. Mode of Utilization: Poultice of leaves and bark are used in rheumatism. Juice of leaves is used for abdominal pain, and bark juice for hepatic diseases. ${ }^{11}$

Ficus semicordata Buch.-Ham ex Sm. Family: Moraceae. Mizo Name: Thei-pui. Mode of Utilization: Leave decoction taken against jaundice and hepatitis. Boils are treated with 
white latex obtained from the tree. ${ }^{2,5,11}$

Firmiana colorata Roxb. Family: Sterculiaceae. Mizo Name: Khau-khim. Mode of Utilization: Infusion of the bark cooked with bark of Citrus medica is taken against tonsillitis. ${ }^{11}$

Flueggea virosa (Roxb. ex Willd.) Voigt. (Figure 3C). Family: Euphorbiaceae. Mizo Name: Sai-siak. Mode of Utilization: All plant parts are used as for eczema, rheumatoid arthritis etc. Leave decoction is used as bathing water for chickenpox, measles, scabies and skin itching. ${ }^{2,4,11}$

Glochidion sphaerogynum (Müll. Arg.) Kurz. Family: Euphorbiaceae. Mizo Name: Thing-pawnchhia/Dawn-dung. Mode of Utilization: Branches and leaves are used as medicine for influenza, eczema, etc. ${ }^{11}$

Gmelina arborea Roxb. Family: Verbenaceae. Mizo Name: Thlan-vawng. Mode of Utilization: Fruit pulp is roasted and applied on skin ailments like rash, sores and itches. ${ }^{4,11}$

Haldina cordifolia (Roxb.) Ridsdale. (Figure 3D). Family: Rubiaceae. Mizo Name: Lungkhup. Mode of Utilization: Bark is used against ulcers, fever, strangury, and dermal problems. Decoction of stem bark with that of Vitex peduncularis is taken orally against fever. Preparations from roots are used in diarrhoea and dysentery. ${ }^{2,11}$

Lagerstroemia speciosa (L.) Pers. Synonym: Lagerstroemia flos-reginae Retz. Family: Lythraceae. Mizo Name: Thla-do/Chawnpui. Mode of Utilization: Stem-bark decoction is useful for diabetes, coronary diseases, dysentery and diarrhoea. Root extract of the tree is used against jaundice. ${ }^{2,4,11}$

Lannea coromandelica (Houtt.) Merr. Synonym: Lannea grandis Engler. Family: Anacardiaceae. Mizo Name: Tawi-taw-suak/Zawng-tawi-taw. Mode of Utilization: Juice both applied externally and taken orally as analgesic for bodyache and against fish allergy. ${ }^{2,11}$

Litsea monopetala (Roxb.) Pers. Family: Lauraceae. Mizo Name: Nau-thak. Parts Used: The roots, bark and leaves of Litsea monopetala have medicinal uses. ${ }^{11}$

Macaranga indica Wight. Family: Euphorbiaceae. Mizo Name: Hnah-khâr/Khâr-paw. Mode of Utilization: Gum is externally applied on sores. Different plant parts are used in numerous traditional medicines. ${ }^{11}$

Mangifera indica Linn. Family: Anacardiaceae.
Mizo Name: Thei-hai. Mode of Utilization: Young leaves decoction is taken orally for diabetes and diarrhoea, ash of dried leaves is used to treat hiccough. Fruit contains vitamins $A$, $B$ and $C^{11}$

Mesua ferrea Linn. (Figure 3E). Family: Clusiaceae. Mizo Name: Herh-se. Mode of Utilization: Infusion of flowers used for dysentery, bleeding piles and cough. Flowers and leaves used as astringent and against snakebite and scorpion sting. Fruit is crushed and applied on scabies and cuts. ${ }^{2,4,6,11}$

Millettia pachycarpa Benth. (Figure 3F). Family: Fabaceae. Mizo Name: Ru-lei/ Ru-zal. Mode of Utilization: Root infusion applied on toothache, wounds, swellings and sprains, scabies and itches. $^{5,6}$

Oroxylum indicum (L.) Benth. ex Kurz. (Figure 3G). Family: Bignoniaceae. Mizo Name: Ar-chang -kâwm. Mode of Utilization: Seeds and bark are used as analgesic and to reduce inflammation. Root bark decoction is used in fevers, various stomach disorders, cancer, asthma, cough, hiccup etc. Bark poultice is applied to bone and skin diseases. Leave decoction is used in headache, flatulence, ulcers, cancer etc. and the fruits for cramp, pulmonary diseases, bronchitis, digestive disorders, leucoderma, piles, etc. Goiter is treated with roasted pod. ${ }^{2,6,11}$

Parkia timoriana (DC.) Merr. Family: Mimosaceae. Mizo Name: Zawng-țah. Mode of Utilization: Tender leaves and seeds are used against food allergy, indigestion, dysentery and diarrhea. The bark and fruits are taken during menstruation against excessive bleeding. The green rind of the pod is juiced and applied to wounds and itches. ${ }^{2,11}$

Persea Americana Mill. Family: Lauraceae. Mizo Name: Butter thei. Mode of Utilization: Infusion of leaves is used against stomach ulcer. The fruits, flowers and seeds of Persea Americana are also used as medicines. ${ }^{11}$

Phyllanthus emblica L. Family: Phyllanthaceae. Mizo Name: Sun-hlu. Mode of Utilization Crushed bark juice is used in pulmonary diseases, diarrhea and dysentery. Bark infusion is applied on rash or sores. Water from soaked pounded fruits is taken for retained placenta and also on skin eruptions due to food allergy. Liquid prepared from boiling of the fruits is taken for diabetes. Dried fruits are taken for queasiness, diarrhoea and dysentery. ${ }^{2,4,6,11}$

Polyalthia longifolia (Sonner.) Thwaites. Family: 


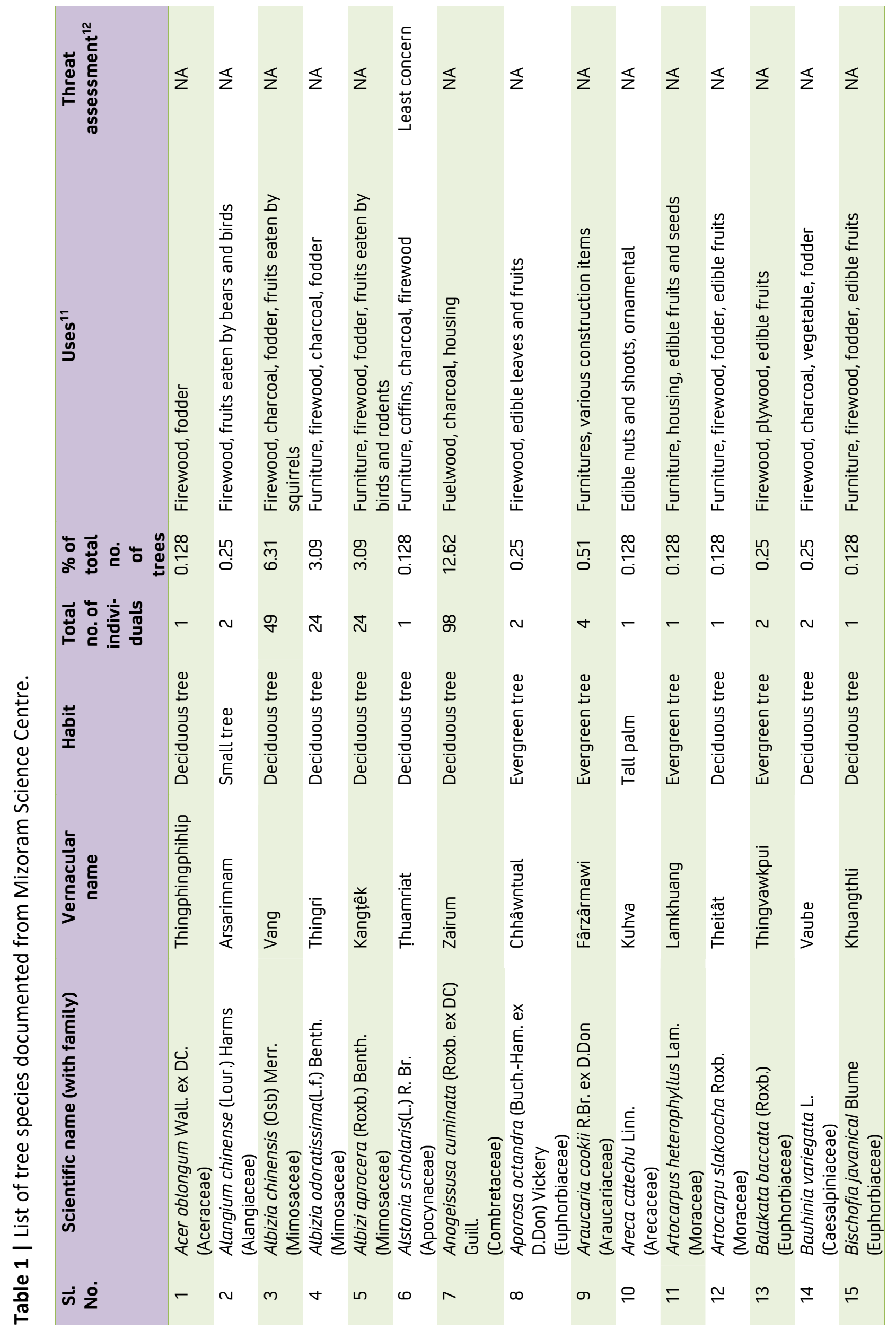




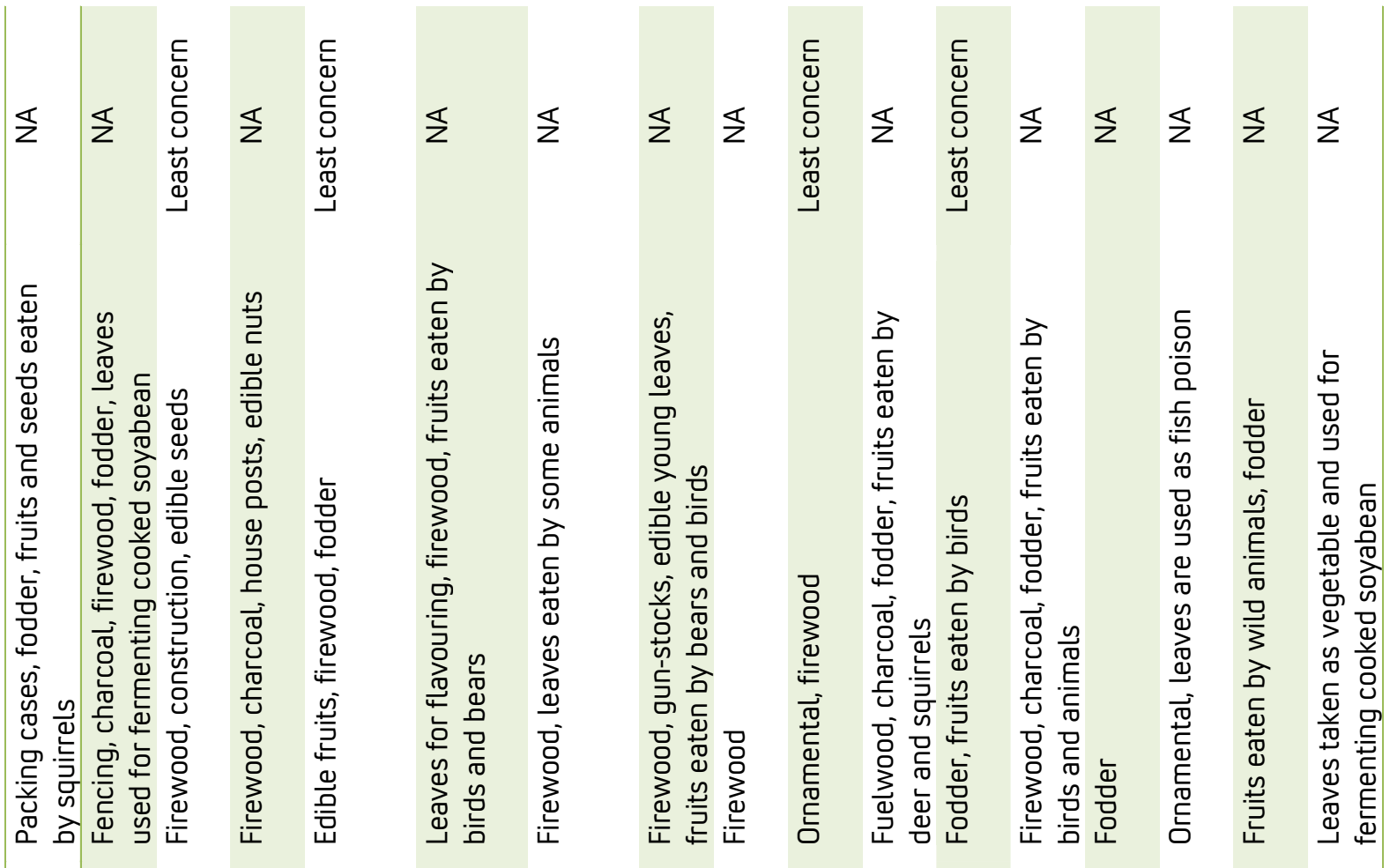

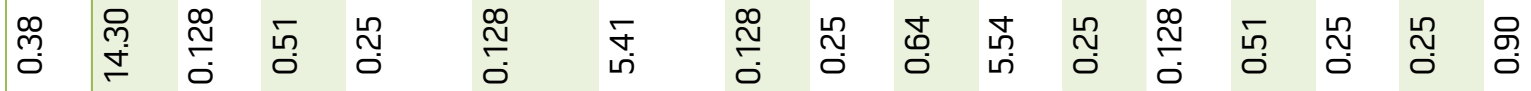

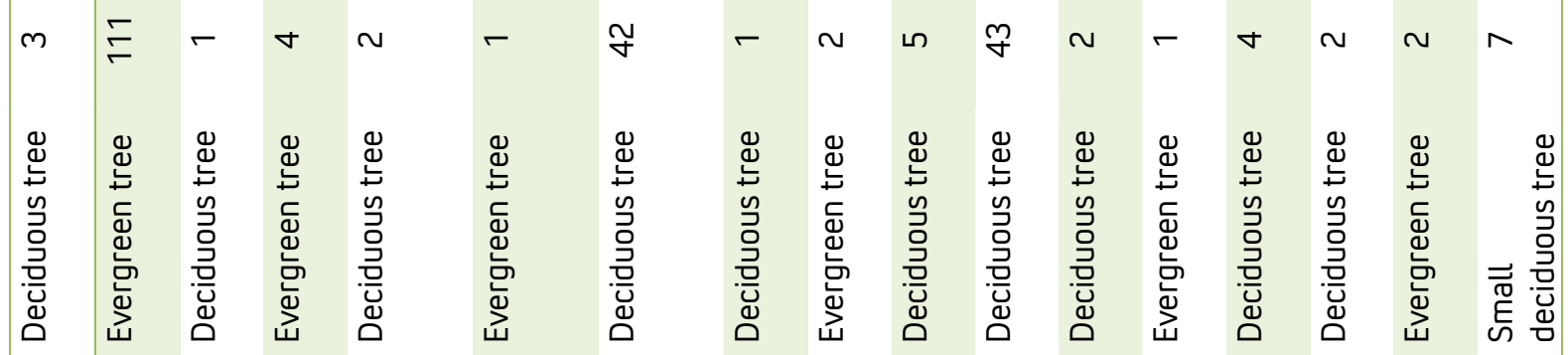

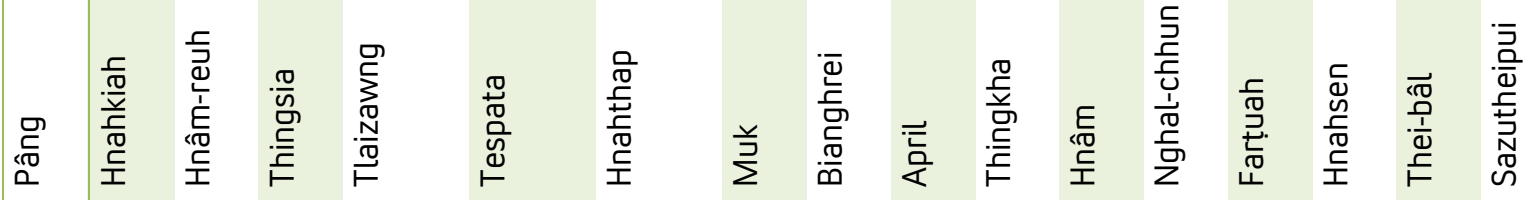

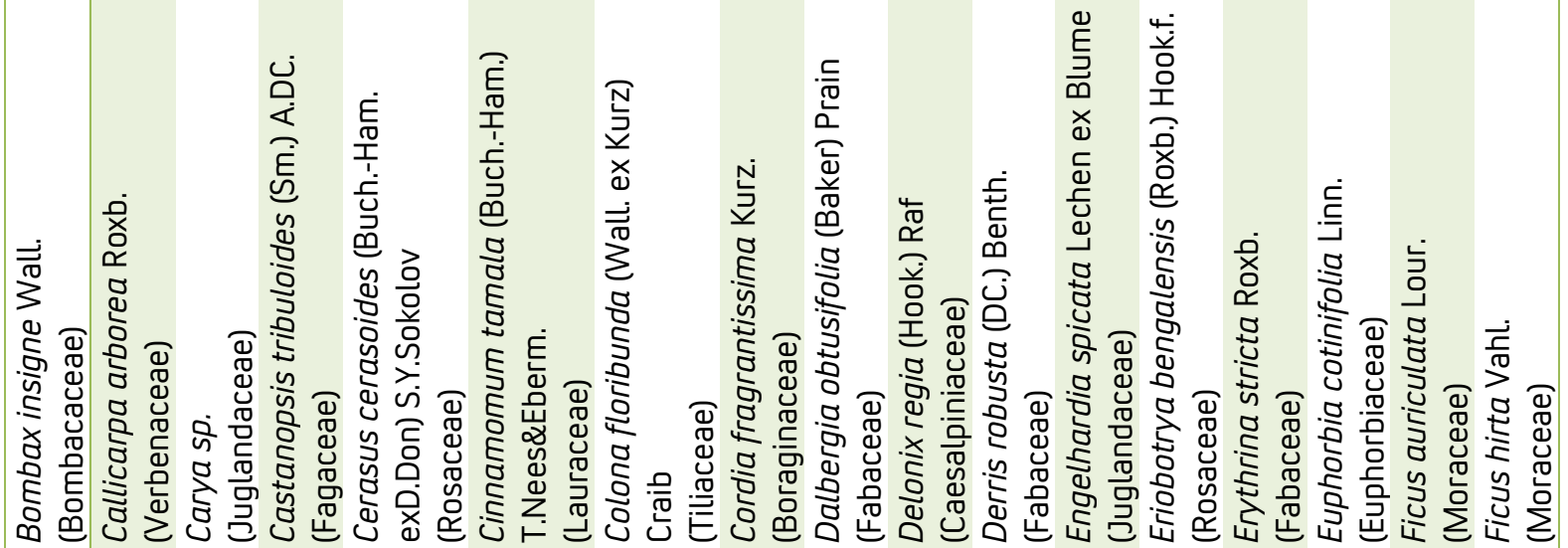

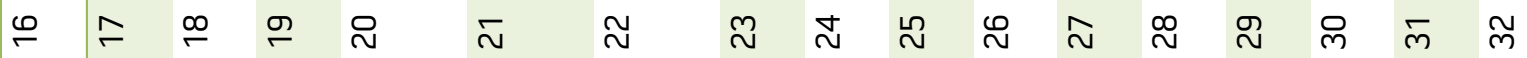




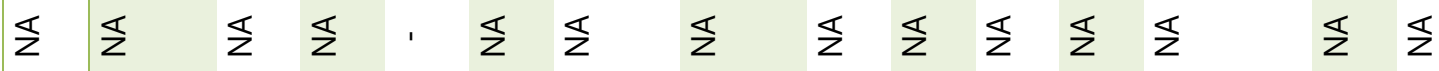
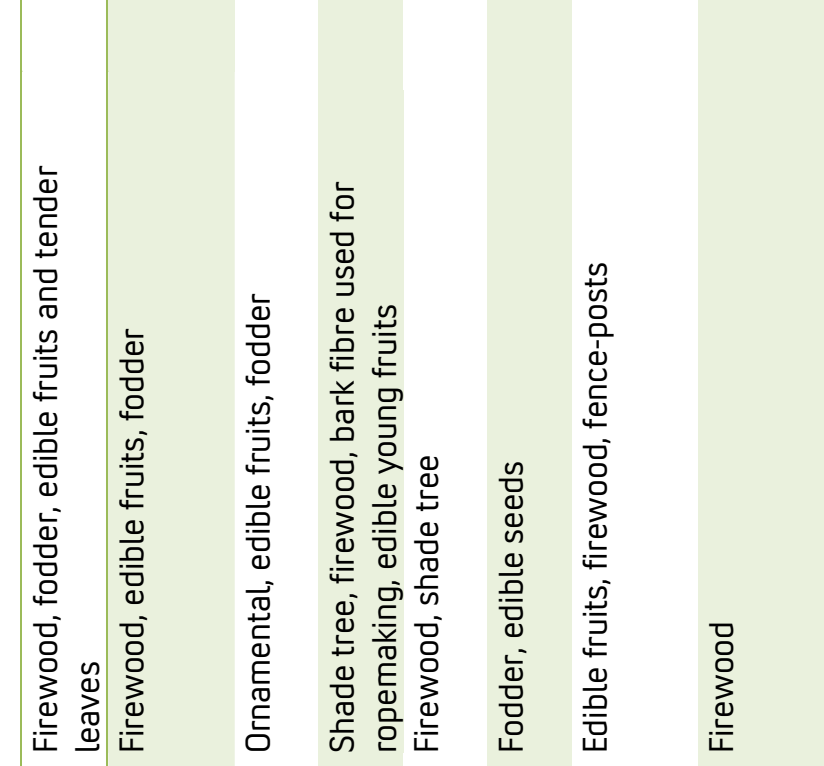

造 $\frac{0}{\frac{0}{0}}$

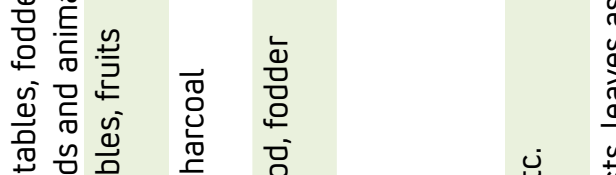

哭

里

芩

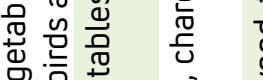

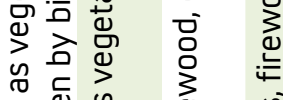

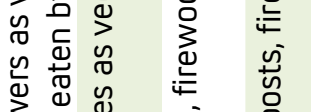

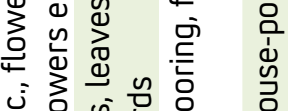

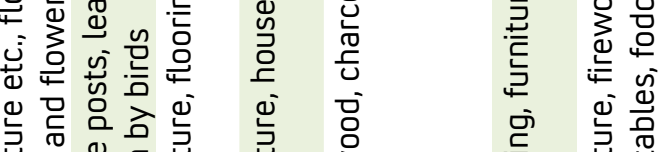

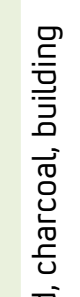
ज苞高 ㅁ⿺ㅇ 离爱

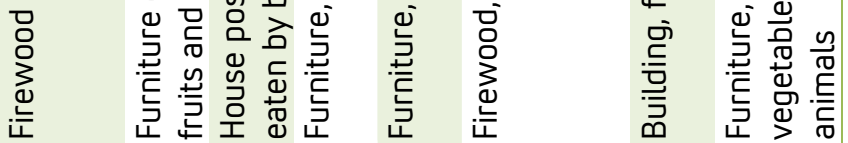

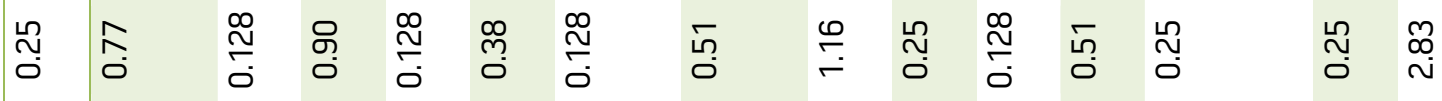
$\sim$

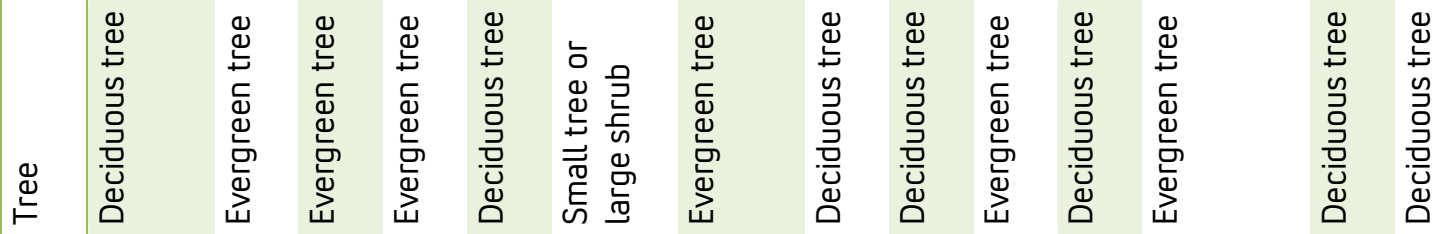

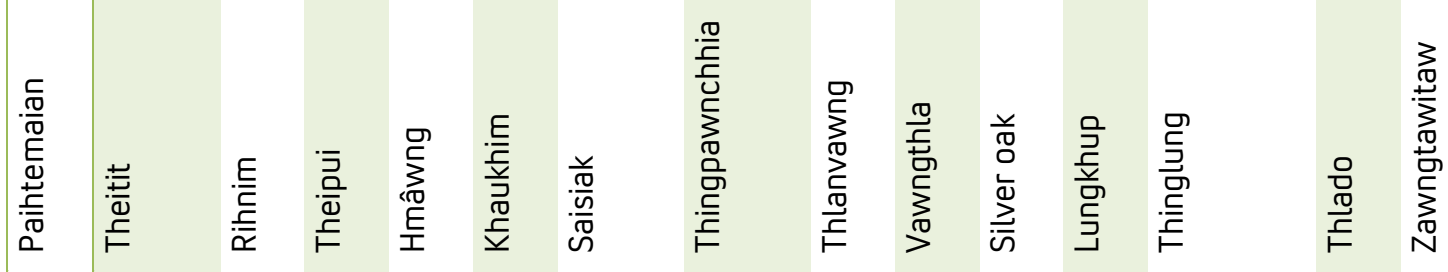

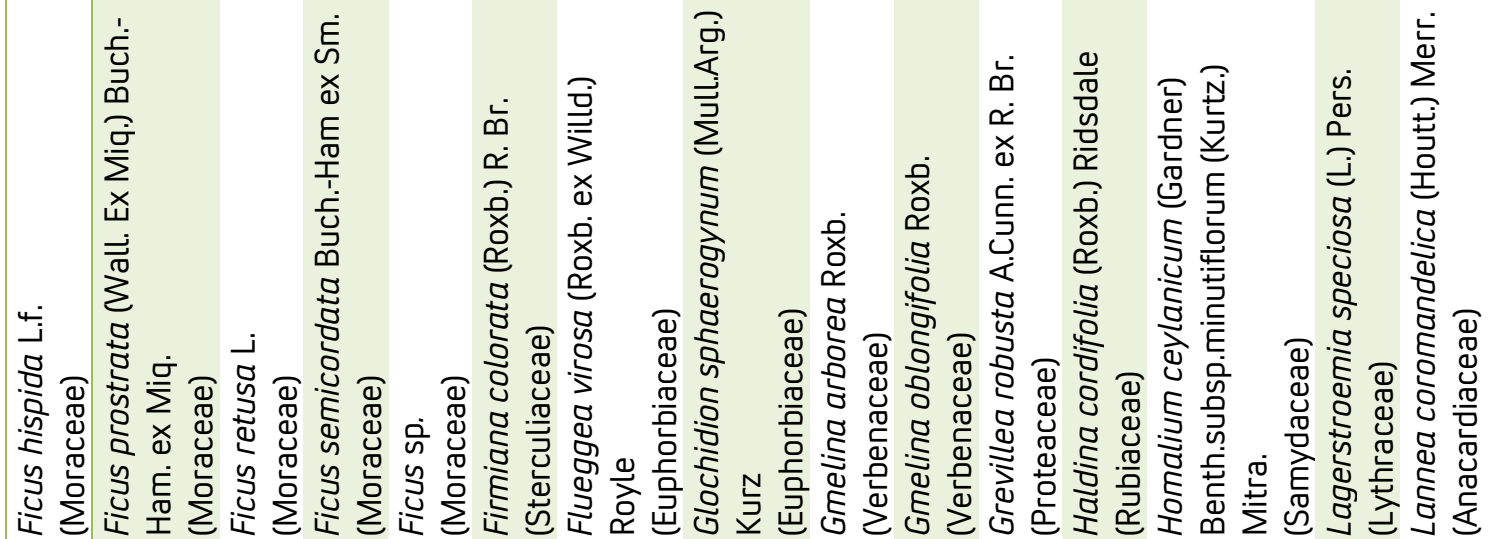

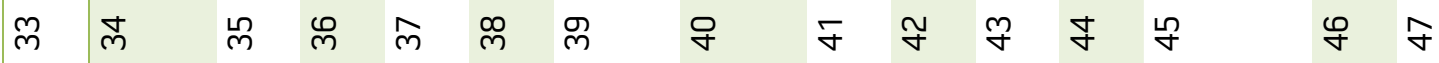




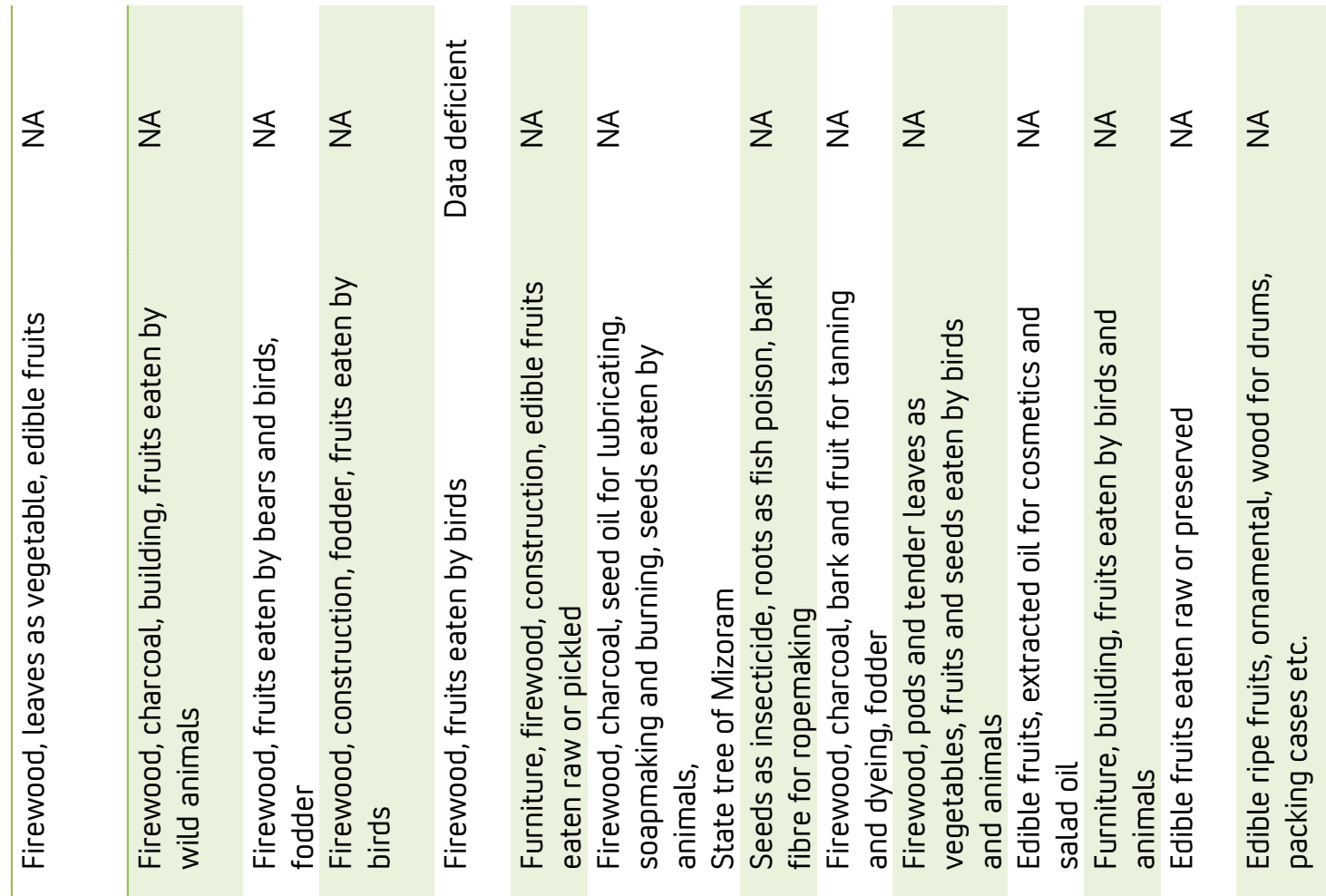

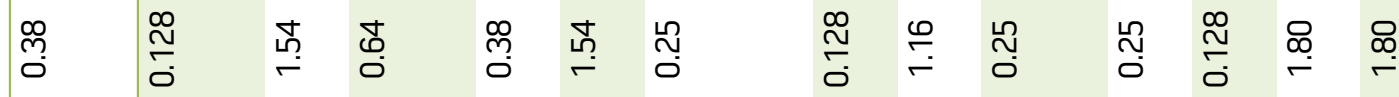

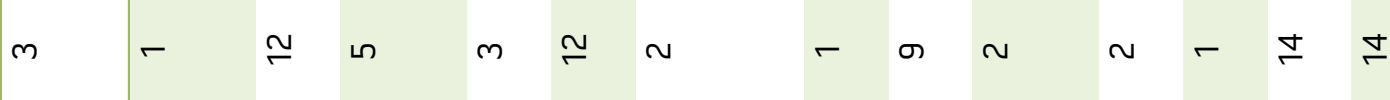

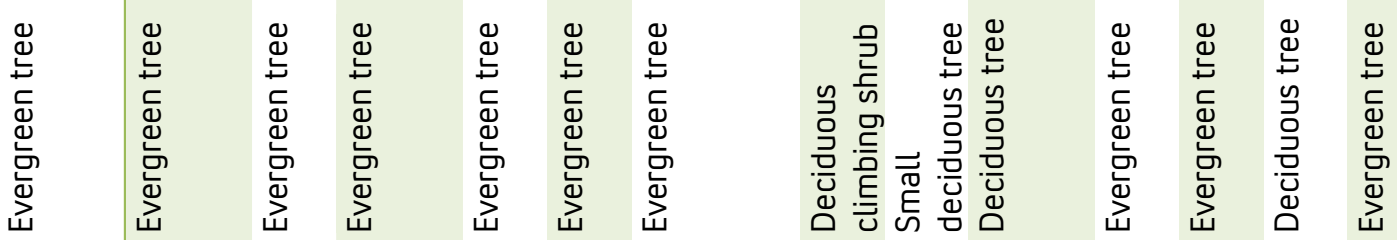

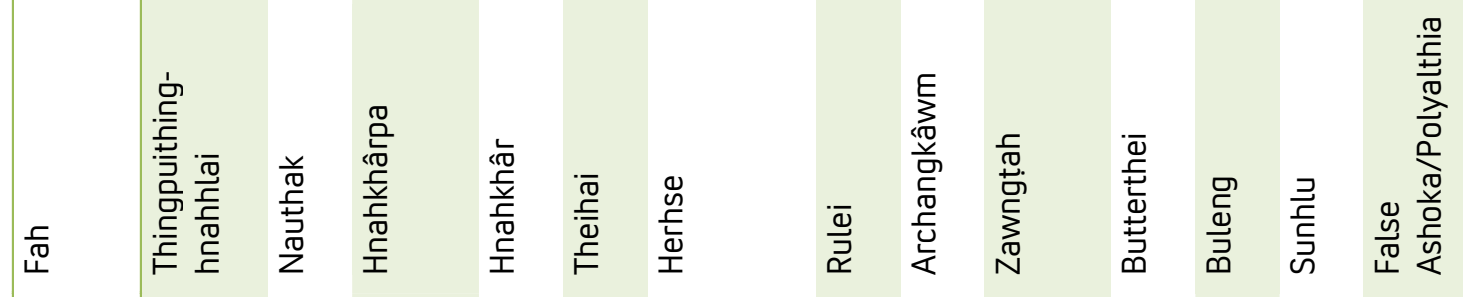

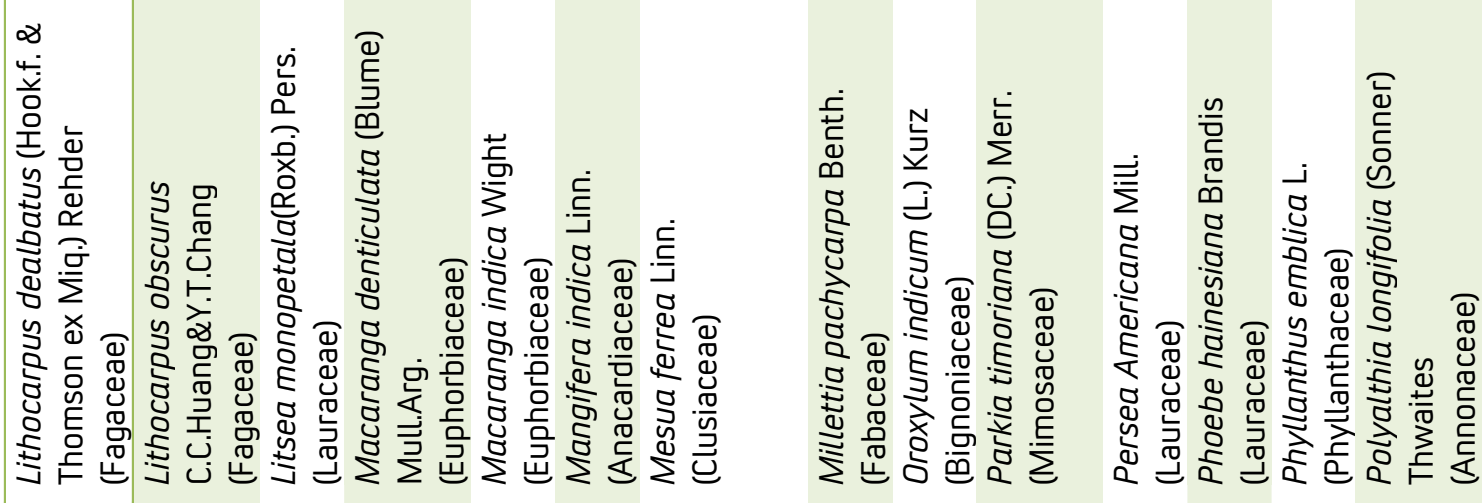

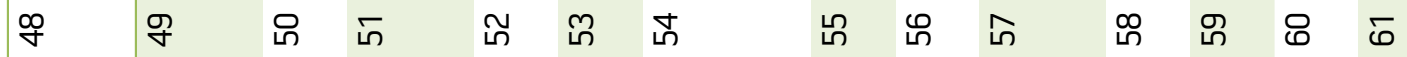



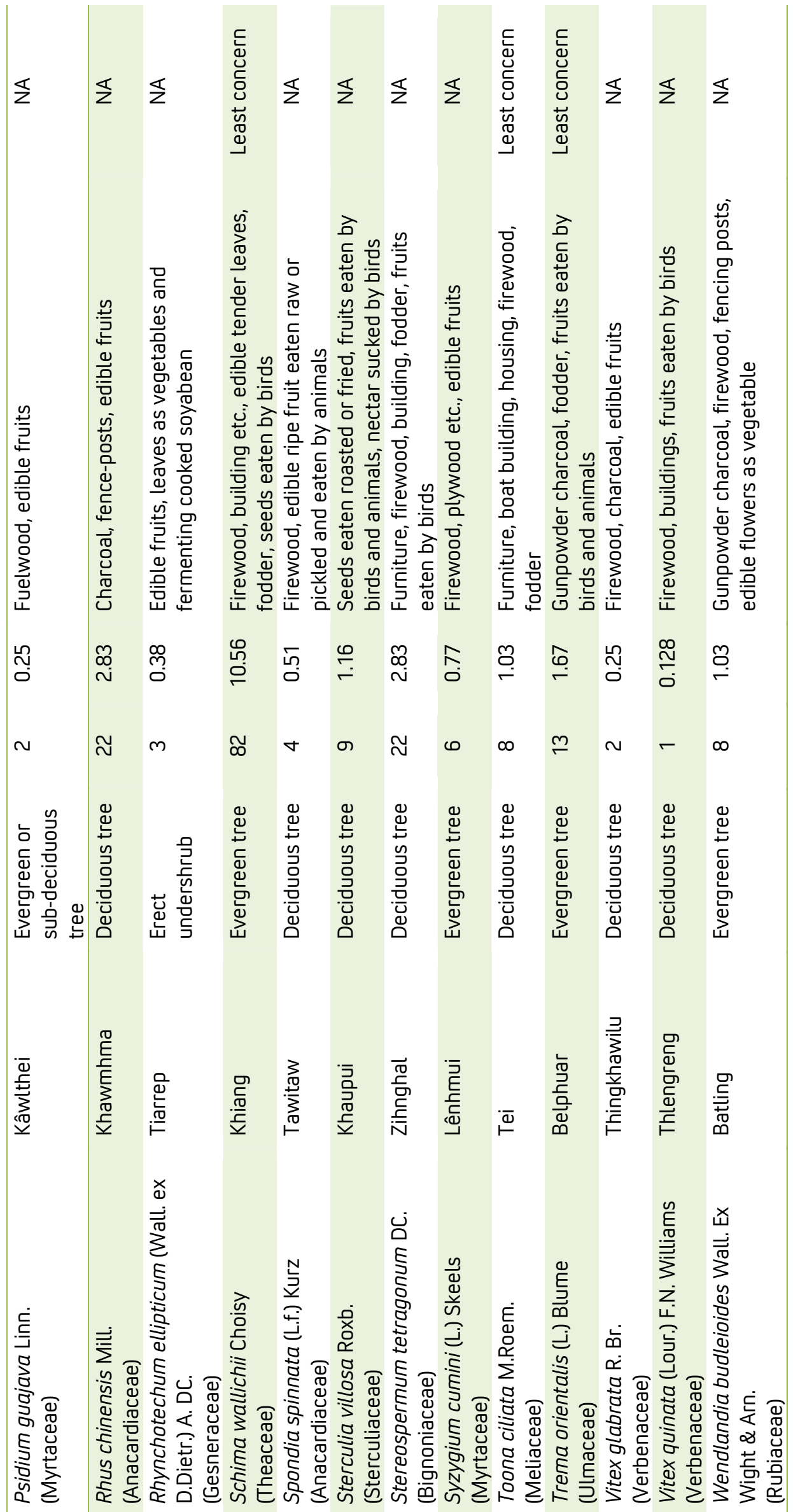

๘ 
Annonaceae. Mizo Name: Polyalthia. Mode of Utilization: Bark is used to reduce fever (febrifuge). ${ }^{11}$

Psidium guajava Linn. Family: Myrtaceae. Mizo Name: Kâwl-thei/Kawi-âm. Mode of Utilization: The bark and tender leaves are taken for diarrhoea and dysentery. The juice obtained from grinding bark, leaves and ripe fruits are useful for boils and sores. Toothache is treated with paste of bark. ${ }^{11}$

Rhus chinensis Mill. (Figure 3H). Family: Anacardiaceae. Mizo Name: Khawm-hma. Mode of Utilization: Fruit decoction is used for indigestion, diarrhoea and dysentery. Water from boiled leaves is used as bathing water against measles, crushed leaves juice is applied to rash or sores. $^{2,11}$

Rhynchotechum ellipticum (Wall. ex D. Dietr.) A. DC. Family: Gesneraceae. Mizo Name: Tiar-rep. Mode of Utilization: Leave decoction is used in cancer treatment. ${ }^{11}$

Schima wallichii Choisy. (Figure 3I). Family: Theaceae. Mizo Name: Khiang. Mode of Utilization: Fruit is powdered and applied on scorpion sting, centipede and spider bites, etc. Sap of the bark is taken for chronic ulcer and applied on snake bites, cuts and wounds. Leave decoction is taken orally for intestinal tapeworms and to relieve flatulence. ${ }^{2,4,11}$

Spondias pinnata (L.f.) Kurz. Family: Anacardiaceae. Mizo Name: Tawi-taw/Tei-taw. Mode of Utilization: Decoction of stem-bark and leaves is taken for rheumatism, diarrhoea, dysentery and fish allergy. The bark if grinded and the juice is applied to cuts. ${ }^{4,11}$

Sterculia villosa Roxb. (Figure 3J). Family: Euphorbiaceae. Mizo Name: Khau-pui. Mode of Utilization: Bark decoction is used in tonsillitis, cholera, dysentery and diarrhoea. Bark fibre juice is taken against threadworm infection. ${ }^{11}$

Stereospermum tetragonum DC. Family: Bignoniaceae. Mizo Name: Zih-nghal. Mode of Utilization: Tender leaves and bark are used against fever, stomachache, etc. Decoctions of leaves and root are used as febrifuge and anthelmintic, leave juice is useful for itches. $2,4,6,11$

Syzygium cumini (L.) Skeels. Family: Myrtaceae. Mizo Name: Lên-hmui/Hmui-pui. Mode of Utilization: Oral medicines include infusion of fruit and decoction of stem-bark and seeds. Seed is taken for diabetes and bark for fever, throat infection, ulcers, jaundice, urinary disorder, respiratory disorders and chronic dysentery. ${ }^{2,11}$

Toona ciliata M. Roem. Family: Meliaceae. Mizo Name: Tei-pui. Mode of Utilization: Stem-bark decoction is taken against for fever, stomach ailments, itching, etc. Extract from flowers are used for treating female menstrual disorders. ${ }^{2,11}$

Trema orientalis (L.) Blume. Family: Ulmaceae. Mizo Name: Bel-phuar. Mode of Utilization: Infusion of root-bark and leaves is used against muscle pain, epilepsy and diarrhea. ${ }^{2,11}$

Vitex glabrata R. Br. Family: Verbenaceae. Mizo Name: Thing-khawi-lu-nu/Thing-ar-ek. Mode of Utilization: Bark and root has astringent properties. Extract from bark of Vitex glabrata is used against typhoid fever. ${ }^{4,11}$

\section{Discussion}

The present study is the first botanical exploration of the tropical semi-evergreen forest at Mizoram Science Centre campus, Berawtlang, Aizawl. In this regard, there is no available record of a similar type of study being undertaken in other science centres in the country. A total of 74 different tree species representing 61 genera and 34 families were recorded in this study, which is lower in comparison to 125 tree species representing 90 genera and 34 families recorded for tropical moist forest of Reiek, Mizoram. However, it was found that the two sites have 29 tree species in common. ${ }^{7}$ Our results reveal that the most abundant tree species at the study site is C. arborea (Hnahkiah) of Verbenaceae comprising of $14.30 \%$ of the total trees assessed, followed by $A$. acuminata (zairum) of Combretaceae with 12.62\%, $S$. wallichii (khiang) of Theaceae with $10.56 \%, A$. chinensis (vang) of Mimosaceae with $6.31 \%, D$. robusta (thingkha) of Fabaceae with $5.54 \%$ and $C$. floribunda (hnahthap) of Tiliaceae with $5.41 \%$. All these dominant species are characterized by edible fruits, seeds, leaves and flowers which form regular food sources for various species of fauna as recorded in Table 1, and thus can be attributed to play a vital role in higher biodiversity and community stability in the area.

Moraceae family has the highest number of species type represented by 9 different species. Seven species of the genus Ficus of Moraceae family have been recorded in the study site, which is comparable to eight Ficus spp. recorded for tropical moist forest of Reiek, Mizoram. ${ }^{7}$ In many tropical forests, the Ficus spp. are found to be key components with a variety of fauna feeding on their fruits. ${ }^{7}$ Other studies have also reported the dominance of Euphorbiaceae and Moraceae in tropical forests including Northern and Eastern Ghats. ${ }^{7,13,14}$ The family Verbenaceae was found to contribute the maximum number of individuals with 
125 trees belonging to 5 species. Similar to the findings of this study, the dominance of angiosperms was reported among the plant species recorded within the Mizoram University Campus, Tanhril, Mizoram, followed by pteridophytes and gymnosperms. ${ }^{15}$ Angiosperms also accounted for $87 \%$ of the total species recorded in 'The Book of Mizoram Plants (Sawmliana, 2003)'.11 A floristic survey of tropical semi-evergreen forest of Reiek (10 sq. $\mathrm{km}$ )in Mamit District of Mizoram has shown the presence of 20 and 18 tree species in the canopy layers of the undisturbed zone and disturbed zone respectively. However, the species composition of this forest shows dissimilarity with our study site with only three species in common, viz. C. tribuloides, S. wallichii and S. cumini. ${ }^{16}$

The top five most abundant tree species of the study site were reported to have ethnomedicinal uses. Among the medicinal plants recorded, Moraceae contributed the maximum number with 7 species and Euphorbiaceae family contributed 5 species. The World Health Organization (WHO) has estimated that traditional medicinal practices are still utilized by around $80 \%$ of the global population. ${ }^{17}$ In Mizoram, documentation of traditional medicinal practices of the native tribal people started some 30 years back. ${ }^{18,19,20}$ Since then, other workers have contributed with more comprehensive reports on ethnomedicinal plants usage in different parts of the region. ${ }^{2,4-6,11} \mathrm{~A}$ large percentage of the population may still be using the traditional herbal medicine. A recent study documented 56 species of medicinal plants used by the local people residing within Aizawl City, the capital of Mizoram. ${ }^{6}$ In recent years, a number of workers have pursued phytochemical screening of the medicinal plants of Mizoram for identifying new drug sources from these phytochemicals. ${ }^{21-23} \mathrm{An}$ analysis of the methanolic extracts of the leaves of $C$. arborea Roxb revealed that it could be a potential source of natural antioxidants. $^{21}$

Another study on twenty traditional medicinal plants used in Mizoram showed that the medicinal properties of these plants may be attributed to the presence of several secondary metabolites such as tannins, alkaloids, saponins, flavonoids, cardioglucosides, phlobatannins and terpenoids in varying degrees in the tested species. ${ }^{22}$ The phytochemicals present in the extracts of Solanum khasianum, Dillenia pentagyna and Croton caudatus used as traditional anticancer medicinal plants in Mizoram were found to show potent anticancer activity on Dalton's lymphoma, MCF-7 and HeLa cell lines. ${ }^{23}$ Conservation of the traditional medicinal knowledge is, thus, particularly crucial for promoting the pharmacological applications of these plants. In order to prevent traditional knowledge from disappearing, a multilevel approach may be taken including training of local practitioners, ex situ and in situ conservation of medicinal plants in botanical gardens and similar protected areas. ${ }^{17}$

\section{Species protection and in situ conservation}

Green plants assume preeminence among all life forms owing to the indispensable role they play for the sustenance of life on earth. Their unique capacity to capture and convert sunlight into chemical energy remains the fundamental source of energy for other higher groups of organisms. In essence, even the enormous reserves of non-renewable petroleum products can be attributed to past photosynthesis. Since time immemorial, plants have been a source of various products including energy-giving foods and flavorings, medicines, coloring materials, cosmetics, perfumes, fibres and fabrics, construction materials for housing and transportation, firewood and fuel wood, and a wide range of other miscellaneous products. ${ }^{24}$ Even today in our modern world, plants continue to provide us the three basic necessities of life - food, shelter and clothing, along with many other life essentials. ${ }^{24}$

On the other hand, forest and forest resources have been drastically exploited by various anthropogenic activities over the past centuries. This overexploitation of plant resources has grave impact on the natural ecosystem balance and also ushers in global climate havoc parallel to it. It has, therefore, become a major agenda worldwide to safeguard and conserve our natural resources. The 2017 assessment of forest cover in Mizoram by Forest Survey of India detected a net decrease of $531 \mathrm{sq} \mathrm{km}$ which was mainly attributed to developmental activities and shifting cultivation. ${ }^{3}$ Protected areas such as biosphere reserves, parks and sanctuaries, in situ gene banks and other restricted places provide protection and in situ conservation to important plant species but the existing protected areas alone are not adequate for species conservation. ${ }^{2}$

In Mizoram, the protected areas cover an area of $1240.75 \mathrm{sq} \mathrm{km}$ which is $5.88 \%$ of its total geographical area, and include Dampa Tiger Reserve, Murlen National Park, Phawngpui National Park, Ngengpui Wildlife Sanctuary, Khawnglung Wildlife Sanctuary, Lengteng Wildlife Sanctuary, Tawi Wildlife Sanctuary, Thorangtlang Wildlife Sanctuary, Pualreng Wildlife Sanctuary and Tokalo Wildlife Sanctuary. ${ }^{25}$ The present study site can also be regarded as a valuable conservation site, where the plant species are not threatened with destructive anthropogenic activities. Additionally, these protected areas may serve as a source for biotechnological interventions to promote micropropagation of selected species. ${ }^{2}$ Threat assessments ${ }^{12}$ in this study revealed that majority of the species have not yet been assessed, while 9 species falls under the Least Concern category. Judicious utilization and conservation of economically important species must therefore, simultaneously be observed to prevent them from becoming endangered and rare. 
Further species diversity studies of other plant forms including herbs, grasses, climbers etc. are crucial to be carried out within the site for enhanced knowledge of the prevailing flora. This will provide a comprehensive backbone of valuable information for management and conservation of available plant resources of the region as a whole.

\section{Acknowledgement}

The authors are grateful for funding received for this study from Directorate of Science \& Technology, Government of Mizoram under SRTIP 2017-2018 (No.B.13012/1/2017-DST). The authors are extremely thankful to H.S. Thapa and Vanlalhruaii Ralte, Department of Botany, Pachhunga University College, Aizawl for their help and support in species identification. The authors also extend sincere gratitude to key informant Lalhmunhluna, Aizawl, and all staff members of MSC for providing all necessary assistance and cooperation for the completion of the work. The authors thank Mizoram Remote Sensing Application Centre (MIRSAC), DST, for preparing location map and satellite image of Mizoram Science Centre.

\section{References}

1. Hrdina, A., Romportl, D. (2017). Evaluating Global biodiversity hotspots - very rich and even more endangered. Journal of Landscape Ecology, 10(1), 108 -115. https://doi.org/10.1515/jlecol-2017-0013

2. Lalramnghinglova, H. (2016). Documentation of medicinal plants based on traditional practices in the Indo-Burma hotspot region of Mizoram, North East India. Emergent Life Sciences Research, 2(1), 1045 .

3. Anonymous (2017). India State of Forest Report. Forest and Tree Resources in States and Union Territorries. Dehradun, India: Forest Survey of India (Ministry of Environment and Forests \& Climate Change). www.fsi.nic.in (10.4.2019)

4. Lalfakzuala, R., Lalramnghinglova, H., Kayang, H. (2007). Ethnobotanical usages of plants in Western Mizoram. Indian Journal of Traditional Knowledge, 6 (3), 486-493.

5. Rai, P.K., Lalramnghinglova, H. (2010). Lesser known ethnomedicinal plants of Mizoram, North East India: An Indo-Burma hotspot region. Journal of Medicinal Plants Research, 4(13), 1301-1307. https://doi.org/10.5897/JMPR09.480

6. Lalzarzovi, S.T., Lalramnghinglova, H. (2016). Traditional use of medicinal plants found within Aizawl City in Mizoram, India. Pleione, 10(2), 269277.
7. Devi, N.L., Singha, D., Tripathi, S.K. (2018). Tree species composition and diversity in tropical moist forests of Mizoram, Northeast India. Indian Journal of Ecology, 45(3): 454-461.

8. Champion, G.H., Seth, S.K. (1968). A Revised Survey of the Forest Types of India. Dehradun, India: Natraj Publishers, p. 404.

9. Armenteras, D., Rodriguez, N., Retana, J. (2009). Are conservation strategies effective in avoiding the deforestation of the Colombian Guyana Shield? Biological Conservation, 42, 1411-1419.

10. Sinha, G.P., Singh, D.K., Singh, K.P. (2012). Flora of Mizoram, Vol II. Kolkata, India: Botanical Survey of India. Ministry of Environment and Forest. Government of India, pp. 469-471.

11. Sawmliana, M. (2003). The Book of Mizoram Plants. Aizawl, India: Zakhuma P., pp. 12--262.

12. IUCN. (2018). The IUCN Red List of Threatened Species. Version 2018-1 www.iucnredlist.org

13. Panda, P.C., Mahapatra, A.K., Acharya, P.K., Debata, A.K. (2013). Plant diversity in tropical deciduous forests of Eastern Ghats, India: A landscape level assessment. International Journal of Biodiversity Conservation, 5, 625-639.

14. Sandhyarani, S., Murth, K.S.R., Pullaiah, T. (2007). Tree flora in Eastern Ghats of southern peninsular India. Research Journal of Botany, 2, 176-185. http:// doi.org/10.3923/rjb.2007.176.185

15. Lalchhuanawma.(2008). Ecological studies on plant diversity and productivity of herbaceous species in Mizoram University campus at Tanhril, Aizawl, Mizoram (N.E. India). Doctoral Thesis. Mizoram University, p. 47.

16. Lalzarzovi, S.T., Lalnuntluanga. (2017). Plant community structure of tropical semi-evergreen forest of Reiek in Mamit District of Mizoram. http://doi.org/10.22232/stj.2017.05.01.08

17. Azaizeh, H., Fulder, S., Khalil, K., Said, O. (2003). Ethnomedicinal knowledge of local Arab practitioners in the Middle East Region. Fitoterapia, 74, 98-108.https://doi.org/10.1016/SO367-326X(02) 00285-X

18. Darlianthanga, C. (1989). Fa Duhthlan Dan leh Mizo Damdawi. Aizawl, India: D. Darlianthanga Publication, pp. 1--26.

19. Lallianthanga. R.K. (1990). Medicinal Plants of Mizoram (A project report). Aizawl, India: Mizoram Council of Science, Technology and Environment, pp. 1-22.

20. Vailinga, M. (1991). Mizo Pipute Sulhnu leh Mizo Damdawi. Lunglei, India: Christian Book Store, pp. 
$1-27$.

21. Lalawmpuii, R., Lalhriatpuii, T.C., Lalzikpuii, Lalengliani, K., Ghosh, S.K. (2015). Qualitative phytochemical screening and evaluation of in-vitro antioxidant activity of Callicarpa arborea Roxb, an ethnomedicinal plant of Mizoram, Northeast India. Asian Journal of Pharmaceutical and Clinical Research, 8(5), 202-205.

22. Lalrinzuali, K., Vabeiryureilai, M., Jagetia, G.C. (2015). Ethnomedicinal use and phytochemical analysis of selected medicinal plants of Mizoram, India. Trends in Green Chemistry, 1, 1-9. https:// doi.org/10.21767/2471-9889.100009
23. Rosangkima, G., Jagetia, G.C. (2015). In vitro anticancer screening of medicinal plants of Mizoram state, India, against Dalton's lymphoma, MCF-7 and HeLa cells. International Journal of Scientific Research, 6(8), 5648-5653.

24. Kochhar, S.L. (2011). Economic Botany in the Tropics ( $4^{\text {th }}$ edition). New Delhi, India: Macmillan Publishers India Ltd., pp. 1--5.

25. Anonymous. (2017). Protected Areas. Department of Environment, Forests \& Climate Change, Government of Mizoram. https:// forest.mizoram.gov.in. (8/4/2019). 